\title{
5. NANNOFOSSIL BIOSTRATIGRAPHY AT SITE 585, EAST MARIANA BASIN ${ }^{1}$
}

\author{
James A. Bergen, Department of Geology, Florida State University ${ }^{2}$
}

\begin{abstract}
Late Aptian through middle Eocene nannofossil assemblages were recovered from a continuously cored section at Site 585. Poorly preserved assemblages of low diversity were observed in samples taken throughout both upper Aptian and/or lower Albian sandstone and mudstone and middle Cenomanian to lower Turonian claystone at the base of this section. A 70-m interval barren of nannofossils separates these poorly preserved assemblages from those recovered from an upper Campanian chalk farther uphole. This chalk marks the most significant change in carbonate deposition at this site, and deposition of interbedded zeolitic claystone and sediment of varied nannofossil content proceeded without major interruption until the early Paleocene (Fasciculithus tympaniformis Zone, CP4). A middle Eocene chalk (dated by nannofossils) unconformably overlies lower Paleocene sediment in both Holes 585 and 585A. Only a few interbeds of zeolitic claystone are present within $100 \mathrm{~m}$ of nannofossil-rich sediment above this unconformity. This entire interval is cautiously assigned to the Discoaster sublodoensis Zone (CP12), which indicates a sedimentation rate almost an order of magnitude higher than expected from normal pelagic sedimentation.

The most obvious feature of the assemblages examined from these cores is the amount of reworked material. Rare Nannoconus elongatus and Braarudosphaera sp. in several upper Campanian to middle Eocene samples demonstrate the contribution of pelagic material from upslope and, along with other reworked species throughout the Upper Cretaceous samples examined, provide evidence contradictory to an excursion of the calcium compensation depth to deep basinal settings in the western Pacific during the Campanian-Maestrichtian time (Thierstein, 1979). The overwhelming dominance of reworked species in all middle Eocene samples examined and the persistence of these assemblages throughout such a large thickness of sediment suggest that currents that redeposited material intensified at this time and may be associated with the formation of the lower Paleocene/middle Eocene unconformity at this site.

A single surface core of calcareous ooze taken from Hole 585A dated as early Pleistocene contains abundant and well-preserved late Miocene and Pliocene species.
\end{abstract}

\section{INTRODUCTION}

Two holes were drilled at Site 585 in the East Mariana Basin (western central Pacific) at a depth of $6109 \mathrm{~m}$. The site is located at $13^{\circ} 29.00^{\prime} \mathrm{N}$ and $156^{\circ} 48.91^{\prime} \mathrm{E}$, approximately $70 \mathrm{~km}$ north of Ita Maitai Guyot and $70 \mathrm{~km}$ east of DSDP Site 199 (Fig. 1). An upper Aptian through middle Eocene section dominated by redeposited sediment was recovered in the continuously cored sequence in Hole 585. Coring of the post-Eocene part of the section was waived in favor of obtaining a Lower Cretaceous and Jurassic section, and a single surface core was the only Neogene material recovered at this site. In Hole $585 \mathrm{~A}, 120 \mathrm{~m}$ of upper Aptian-lower Albian volcaniclastic sediment was cored and represents the subjacent interval below the total depth drilled at Hole 585. Spot cores taken at two intervals above this resampled the Cretaceous/Tertiary boundary and an organic-rich layer near the Cenomanian/Turonian boundary.

Nannofossil assemblages recovered from Site 585 occur in: (1) lower Pleistocene calcareous ooze in Core 585-1; (2) upper Campanian through middle Eocene nannofossil chalk to claystone; (3) middle Cenomanian through lower Turonian claystone and associated sediment; and (4) upper Aptian and/or lower Albian volca-

\footnotetext{
${ }^{1}$ Moberly, R., Schlanger, S. O., et al., Init. Repts. DSDP, 89: Washington (U.S. Govt. Printing Office).

Present address: UNOCAL, P.O. Box 76, Brea, CA 92631.
}

niclastic sandstone and mudstone. The majority of these sediments show evidence of transport and redeposition. Middle Cretaceous sediment contains graded sequences, parallel laminations, injections of shallow-water material, and nearly complete Bouma sequences. Size sorting of foraminifer and radiolarian assemblages and downslope displacement of benthic foraminifers are additional evidence of transport (see Site 585 report, this volume). All the nannofossil assemblages show some degree of reworking. The reworking is so pervasive that it renders all last occurrence datums useless, thus reducing biostratigraphic resolution.

\section{METHOD}

Nannofossils were examined by light microscopy from smear slides, and selected samples were centrifuged for photography. Generic and specific names for all the taxa used in this report are listed in order of their generic names in the Appendix. The abundance of individual taxa in a sample was determined at $780 \times$ as follows: more than 10 specimens per field of view $=$ abundant $(A) ; 1$ specimen per field of view $=$ common $(C) ; 1$ specimen per 10 fields of view $=$ few $(F) ; 1$ specimen per 100 fields of view $=$ rare $(R)$; and less than that $=$ present $(\mathrm{P})$. The number of nannofossils in proportion to the total amount of sediment was assessed as follows: greater than $50 \%=$ abundant (A); $10 \%$ to $50 \%=$ common (C); $1 \%$ to $10 \%=$ few (F); less than or equal to $1 \%=$ rare $(R)$; and barren (B). The quality of preservation was determined as good $(G)$, moderate $(M)$, or poor $(P)$.

Tertiary strata were zoned according to the scheme of Okada and Bukry (1980). The zonation utilized for Upper Cretaceous sediments is that of Verbeek (1977). Middle Cretaceous strata were not assigned to specific zones, and their age determinations are based on Thierstein (1976), Manivit et al. (1977), and Perch-Nielsen (1979). Range charts are presented in Tables 1 through 5 . 


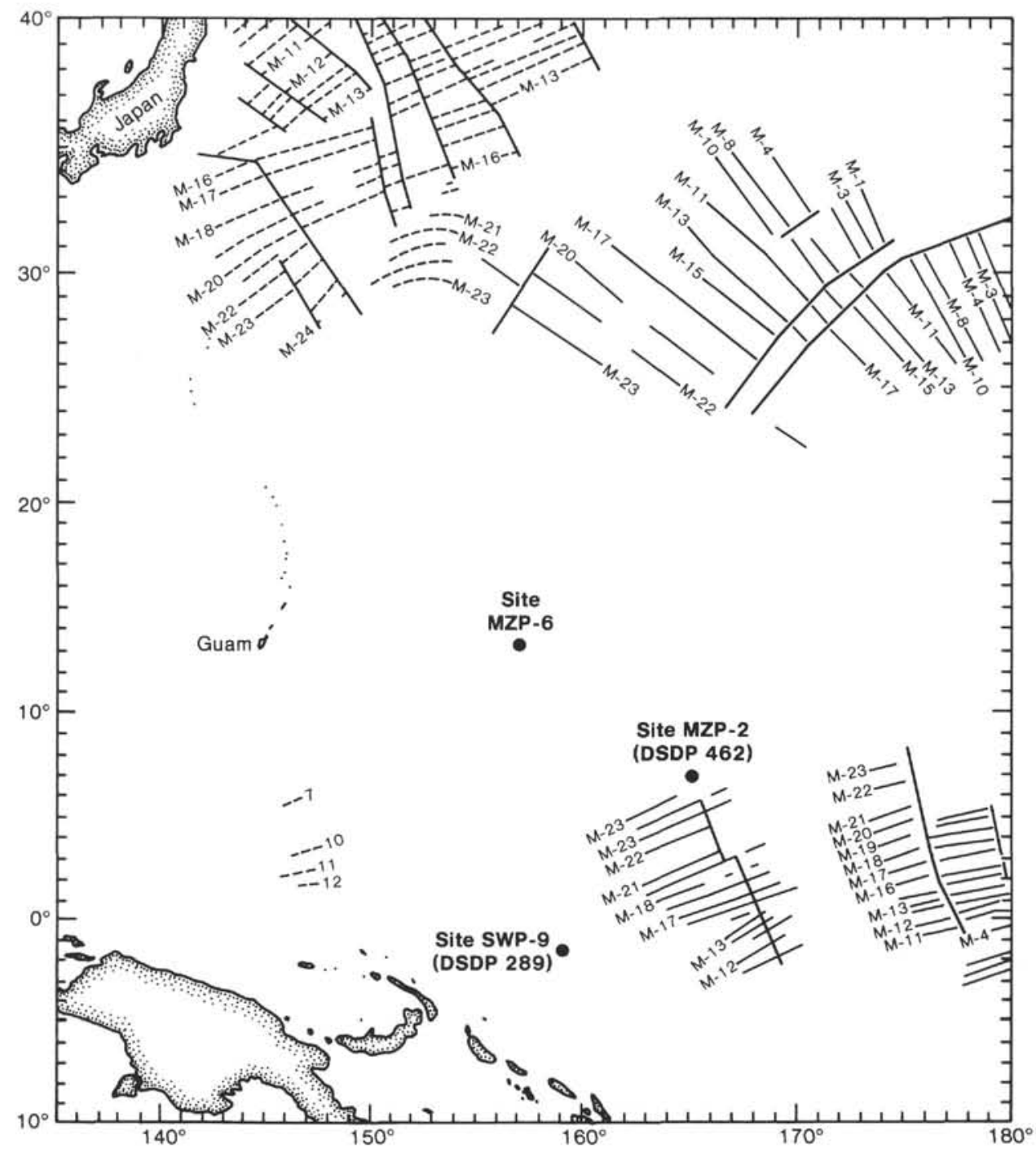

Figure 1. Site location map.

\section{DISTRIBUTION OF CALCAREOUS NANNOFOSSILS AT SITE 585}

\section{Neogene}

Samples 585-1-3, 84-85 cm and 585-1,CC contain a mixed assemblage in which there are rare specimens of Gephyrocapsa caribbeanica and Pseudoemiliania lacunosa. The early Pleistocene age indicated by the co-occurrence of these two poorly preserved species is in agreement with the planktonic foraminifers (Premoli Silva, this volume). Upper Miocene through Pliocene species are abundant and well-preserved in these samples. Among the forms present are common Discoaster brouweri, Discoaster surculus, Discoaster pentaradiatus, Reticulofenestra pseudoumbilica, Sphenolithus abies, and Sphenolithus neoabies. Few Discoaster quinqueramus and rare Ceratolithus rugosus are also present. The calcareous ooze in Core $585-1$ is interpreted as a distal turbidite (Site 585 report, this volume).

\section{Campanian through Middle Eocene}

(Cores 585-2 to -21 and 585A-1 to -3; Tables 1 and 2)

Sediments recovered from this interval are dominantly nannofossil chalk and zeolitic claystone, with minor amounts of silicified limestone, nannofossil limestone, chert, and calcareous clay. In Hole 585, Cores 2 to 7 are characterized by a mixture of all the above lithologies as drilling breccia. Below this, nannofossil chalk is dominant. Zeolitic claystone is most commonly interbedded within the chalk. Claystone is first present in Core 13, increasing in abundance downhole. In Cores 17 to 21 , claystone is common and interbedded with sediments of varied nannofossil content. The three spot cores taken across the Cretaceous/Tertiary boundary in Hole 585A contain interbedded nannofossil-bearing sediment and zeolitic claystone.

The frequent alternations in lithology of such varied nannofossil content (Cores 585-16 to -21 ; $585 \mathrm{~A}-1$ to -3 ) 
are believed to result from the deposition of distal turbidites between periods of pelagic sedimentation, as represented by the zeolitic claystone (Site 585 report, this volume). Nannofossil assemblages recovered from zeolitic claystone commonly contain reworked species and are concentrated in laminations and stringers of lighter-colored sediment within the claystone. Thus assemblages from zeolitic claystone may represent injections of allochthonous material during a period of dominantly pelagic sedimentation.

Reworked specimens are common in many assemblages from these cores. Cretaceous species reworked into Tertiary sediments are so abundant that they obscure the Cretaceous/Tertiary boundary. Most Cretaceous species show no change in abundance across this boundary.

In Hole 585, a late Campanian age is determined for Section 585-20-3 to Core 585-21. Ceratolithoides acule$u$ s is present at the bottom of Core 21 and Quadrum trifidum has its first occurrence in Section 585-20-3. Core 585-18 to Section 585-20-3 contain Quadrum trifidum but not Micula murus, and a late Campanian to early Maestrichtian age is determined for this interval. Micula murus is first observed in Sample 585-17-2, 7-8 cm and is also present at the base of Core 585A-3, dating this interval as Iate Maestrichtian.

The Cretaceous/Tertiary boundary was cored in both holes. In Hole 585, the first occurrence of Zygodiscus sigmoides and the increase in the abundance of Thoracosphaera were used to determine the boundary. The appearance of Neocrepidolithus neocrassus, Cyclagelosphaera reinhardtii, and a slight increase in the number of Thoracosphaera were used as criteria in Hole 585A. $Z y$ godiscus sigmoides is first seen in Sample 585A-3-1, 64-65 cm (the next sample above the boundary).

The first appearance datums of Cruciplacolithus tenuis (CP1) and Chiasmolithus danicus (CP2) were observed in basal Paleocene sediments from both holes. Their first occurrences are coincident in Hole 585, but not in Hole 585A. This is probably the result of either low core recoveries or incomplete sampling. Sediments overlying Danian samples were assigned to the Fasciculithus tympaniformis Zone (CP4), as the Ellipsolithus macellus Zone (CP3) was not detected at this site.

A significant hiatus is represented below the middle Eocene sediments that unconformably overlie the lower Paleocene deposits. This unconformity occurs between Cores 14 and 15 in Hole 585 and, in Hole $585 \mathrm{~A}$, between Samples 585A-1-1, 95-96 cm and 585A-1-1, 132$133 \mathrm{~cm}$ in Hole 585A. Nannofossils are common and poorly preserved in sediments just below this contact and are abundant and moderately preserved in the chalk above. The relative species abundances in the thirteen cores (585-2 to -14) above the unconformity are very consistent, although there are fluctuations in nannofossil content. The middle Eocene age determined for this entire interval is tentative. Extremely rare and overgrown specimens of Discoaster lodoensis and Discoaster sublodoensis occur in all but three samples from these cores (all three of which contain few, poorly preserved nannofossils), but co-occur with abundant and well-preserved Paleocene forms. Cretaceous species comprise 5 to $10 \%$ of all assemblages. The reworking is so extensive in these sediments that all the Paleocene marker species of Okada and Bukry (1980) can be found in several samples. Coccolithus formosus and Discoaster barbadiensis are the only other Eocene forms found in this interval, except for Tribrachiatus contortus in Sample 585-4,CC. A cursory examination of slides from these cores would indicate a late Paleocene age, because common Discoaster multiradiatus, Campylosphaera eodela, and Tribrachiatus nunnii are present. It is possible that the rare Eocene species are contaminants, but none are found in samples studied below the unconformity.

\section{Middle Cenomanian through Early Turonian (?)}

\section{(Cores 585-28 to -35 and 585A-5 to -10; Tables 3 and 4)}

Poorly preserved assemblages occur throughout these cores. Eiffelithus turriseiffeli, Microstaurus chiastus, and Lithraphidites acutum are found in samples from all these cores. Rare specimens of a rather obscure form, Quadrum gartneri, are first seen in Samples 585-32-1, $42-43 \mathrm{~cm}$ and $585 \mathrm{~A}-8-1,108-109 \mathrm{~cm}$. A tentative early Turonian age is determined for these samples and those above them. This age determination is supported by the foraminifers (Sliter, this volume; Premoli Silva, this volume). If this age assignment is correct, two species restricted to the Cenomanian, Microstaurus chiastus and Lithraphidites acutum, have been reworked into Turonian sediment.

The middle Cenomanian age determination for the base of this interval suggests that a large part of the Albian and some of the Cenomanian are missing or are condensed in the few cores below this interval or that an accurate age cannot be determined for the poorly preserved assemblages downhole.

\section{Late Aptian to Early Albian}

\section{(Cores 585-40 to -55 and 585A-11 to -21; Tables 4 and 5)}

Nannofossils, when present, are rare and poorly preserved in these cores. Eprolithus floralis is present at the base of the section and dates these sediments as late Aptian or younger. Prediscosphaera cretacea, Prediscosphaera columnata, and Rhagodiscus asper are not found in these cores but occur in poorly preserved assemblages above this interval. Thus a late Aptian to early Albian age is determined for this interval.

\section{REWORKED NANNOFOSSIL ASSEMBLAGES}

The most striking feature of the section at Site 585 is the dominance of reworked material. This is reflected in the nannofossil assemblages, which provide information about the age of displaced pelagic material and evidence for current transport. Because only older, non-contemporaneous specimens can be recognized as reworked, the amount of detectable reworking is only a minimal estimate and quantitative changes in it are impossible to document. However, qualitative estimates of the contribution of reworked nannofossils and the age of that ma- 
Table 1. Distribution and abundance of nannofossils in Cores 585-2 to 585-21.

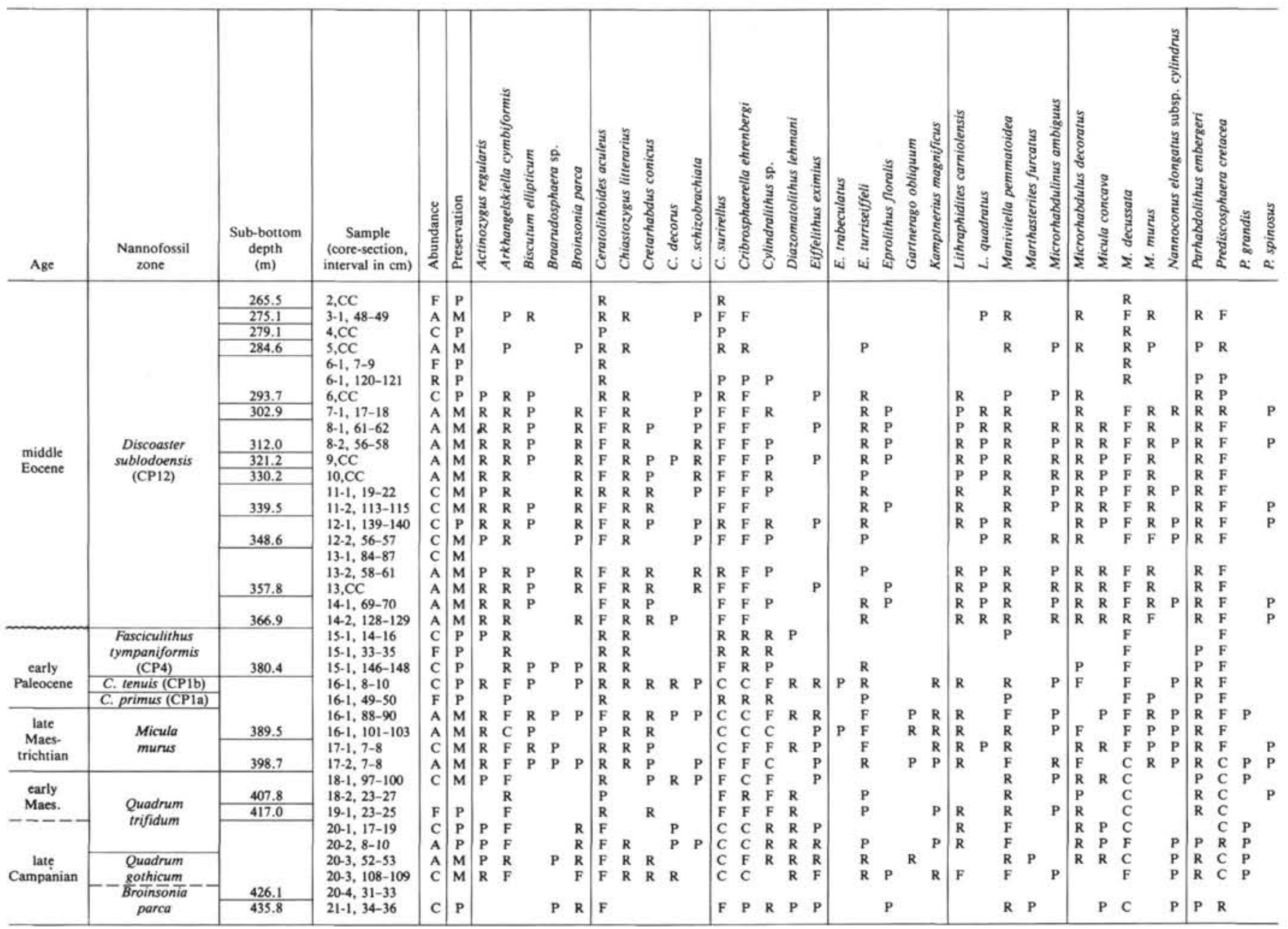

Note: See Methods section of text for explanation of symbols in Tables 1 through 5.

Table 2. Distribution and abundance of nannofossils in Cores 585A-1 to 585A-3.

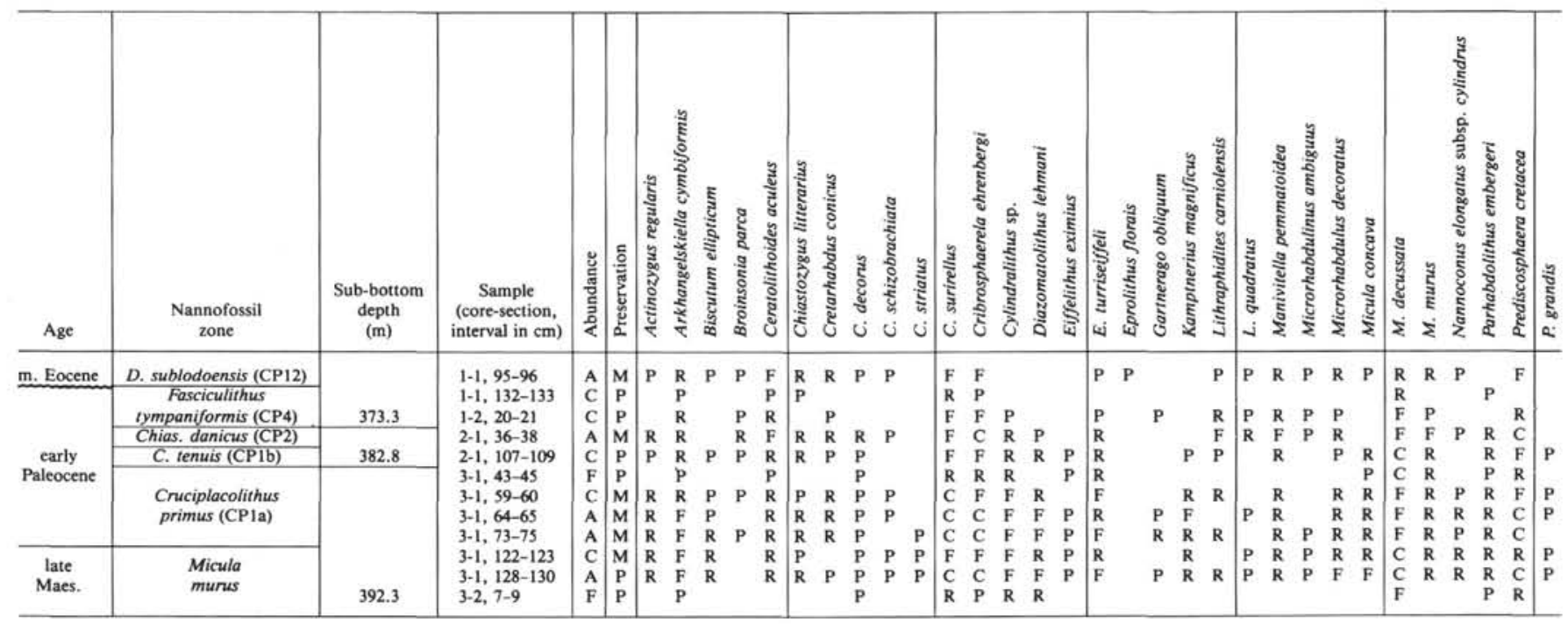


Table 1 (continued).

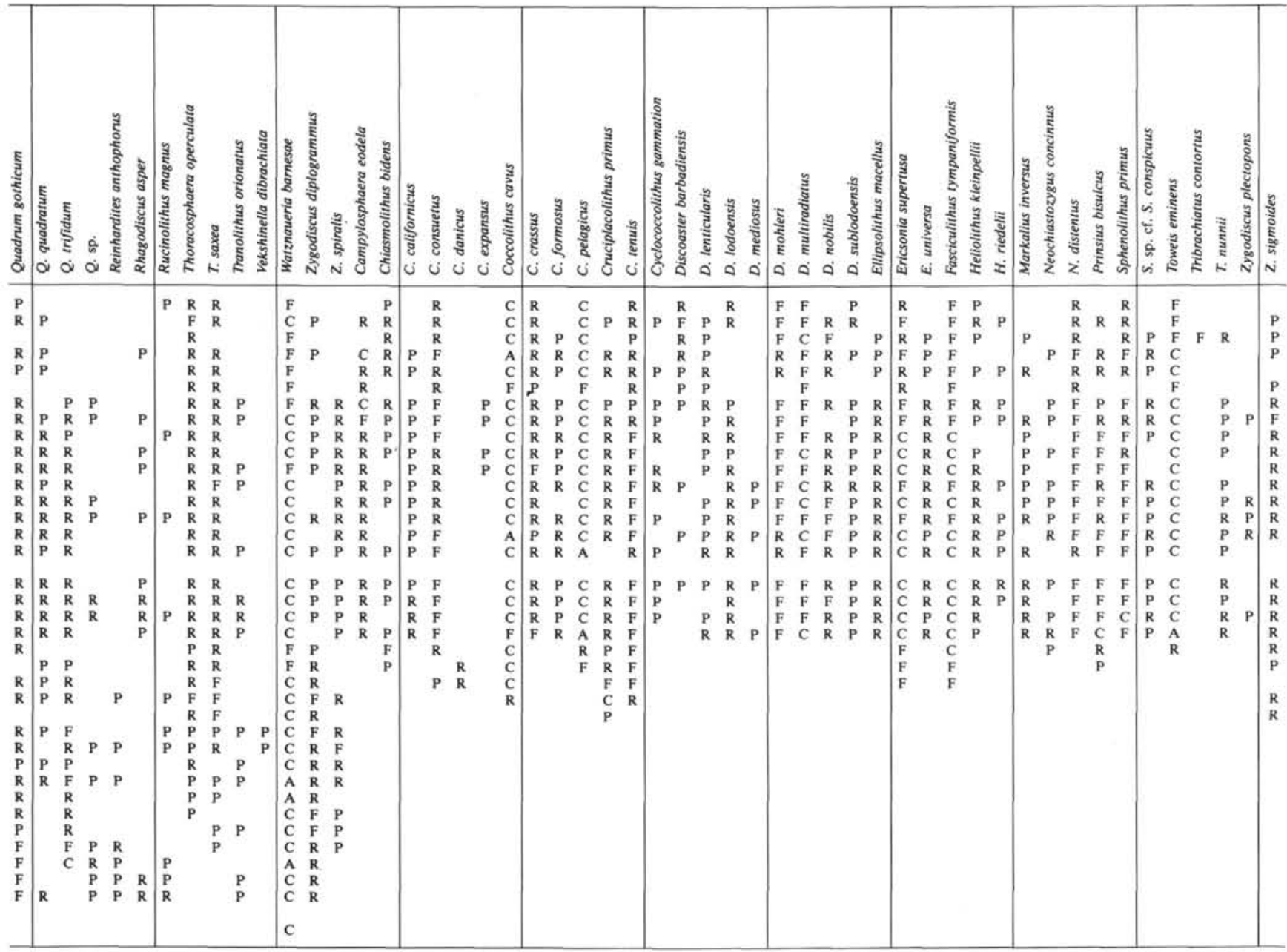

Table 2 (continued).

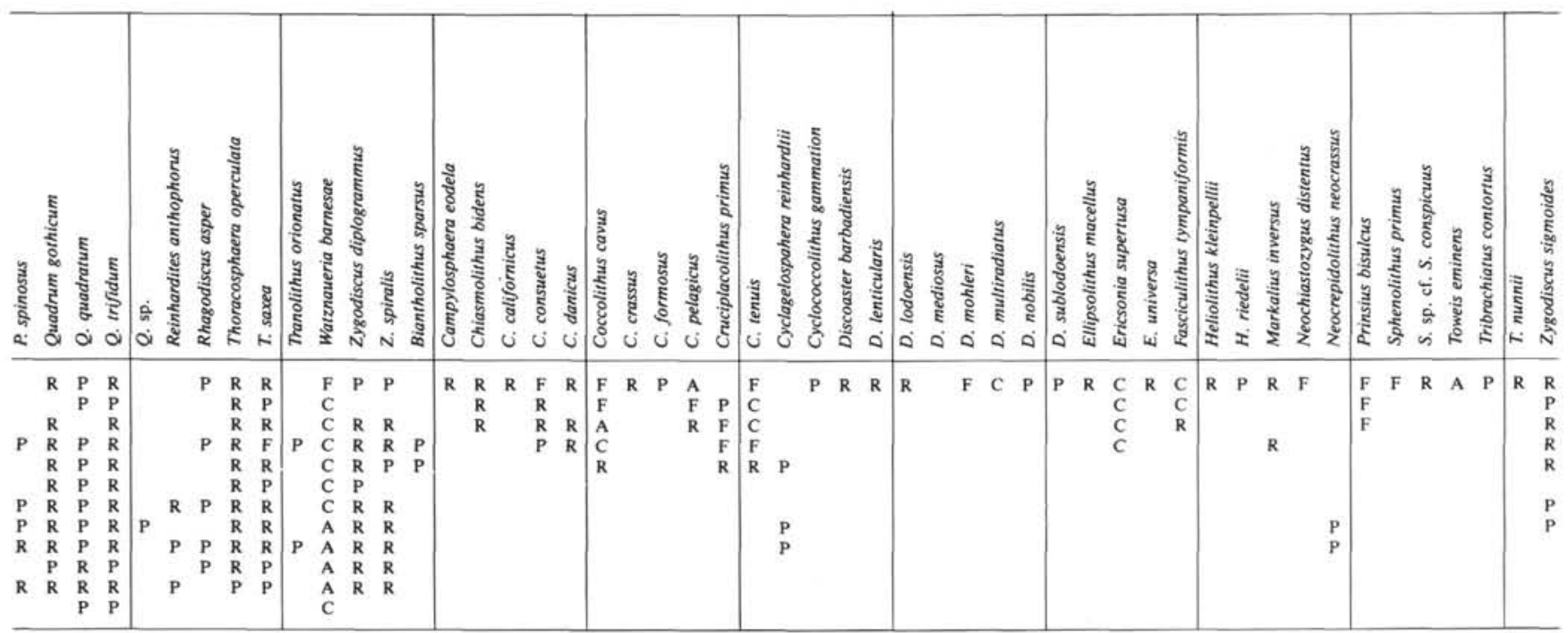


Table 3. Distribution and abundance of nannofossils in Cores $585 \mathrm{~A}-5$ to $585 \mathrm{~A}-10$.

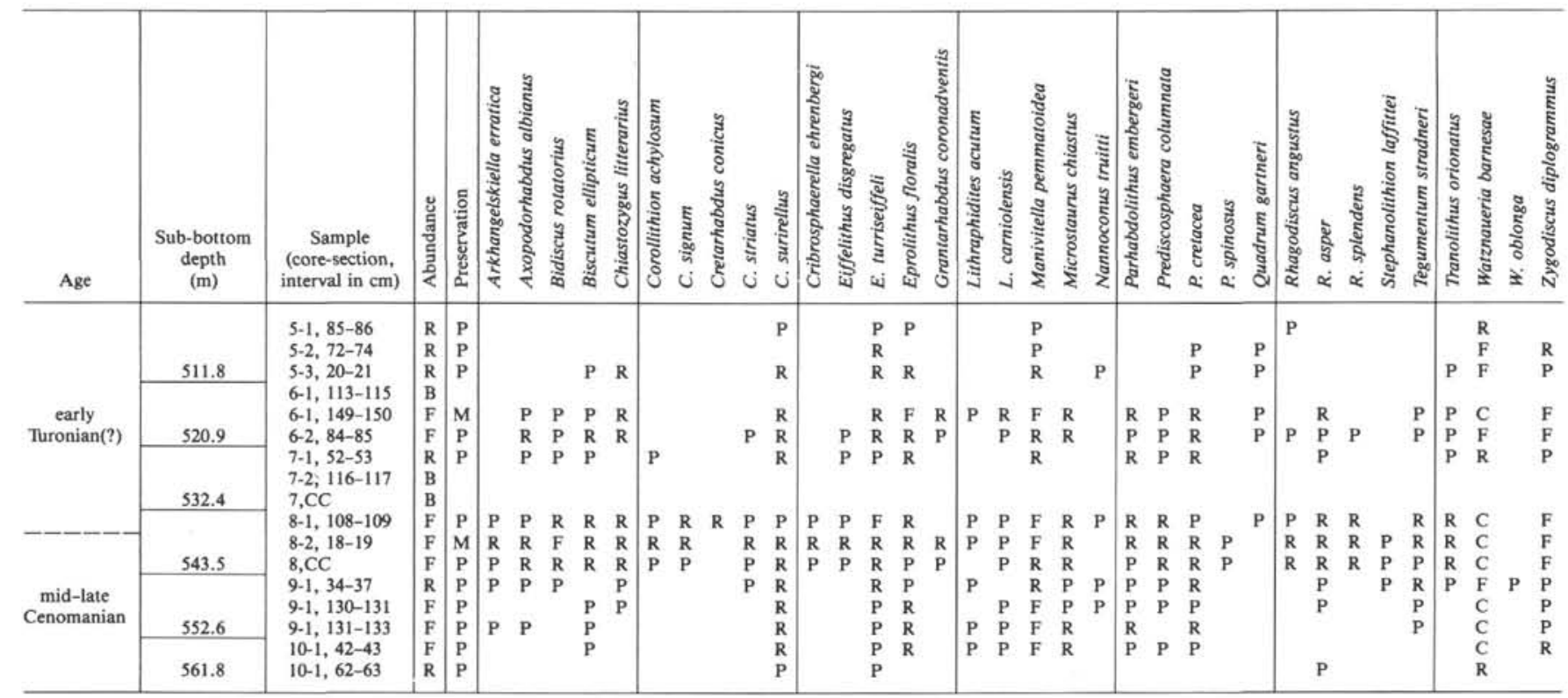

terial can give information on the source and intensity of currents that reworked the material.

At Site 585, reworked nannofossils are most evident in upper Campanian to middle Eocene sediment, especially where Cretaceous forms have been redeposited into Tertiary sediment. Cretaceous species make up 75 to $98 \%$ of assemblages in basal Paleocene sediment and $25 \%$ of the assemblages in overlying sediment of the Fasciculithus tympaniformis Zone (CP4). The sharp decrease in the number of reworked Cretaceous species coincides with a minor hiatus. The Ellipsolithus macellus Zone (CP3), recognized by the first occurrence of the nominative species, was not detected.

Ellipsolithus macellus, however, is reworked into middle Eocene chalks on top of the lower Paleocene deposits, which can be explained by a change in the source of reworked material, or in preservation, or by an increase in the intensity of reworking. Assemblages throughout the thick middle Eocene section $(110 \mathrm{~m})$ are also very consistent and attest to the thorough mixing and perhaps unconsolidated nature of this sediment upon redeposition. Cretaceous species comprise 5 to $10 \%$ of these assemblages, and Paleocene species always overwhelm the rare Eocene species in these samples. The complete dominance of reworked nannofossils throughout sediments above the unconformity implies that currents that redeposited material at this site intensified at this time. Because this sediment also belongs to one nannofossil zone (Discoaster sublodoensis Zone), the thick units of nannofossil-rich sediment may be interpreted as rapidly deposited distal turbidites interrupted by short periods of pelagic sedimentation (zeolitic claystone).

Reworking within Campanian and Maestrichtian assemblages is more difficult to identify because most of the common Late Cretaceous species are long ranging. Quadrum trifidum, Broinsonia parca, Reinhardtites an- thophorus, Eiffelithus eximius, and Quadrum gothicum, species normally having their extinctions in this age sediment, are all reworked into younger horizons. Rare Marthasterites furcatus and Eprolithus floralis in some samples from this interval represent redeposited pre-late Campanian forms. Of special interest are rare Nannoconus elongatus and Braarudosphaera sp. (see the taxonomy section that follows) in several upper Campanian through middle Eocene samples. Nannoconids are commonly associated with marginal settings (Thierstein, 1976; PerchNielsen, 1979). Recent Braarudosphaera occur in sediments of less than $3 \mathrm{~km}$ depth (Thierstein, 1980; Thierstein and Manivit, 1981). The occurrence of Braarudosphaera sp. at Site 462 in samples with indigenous abyssal benthic foraminifers has been used to support evidence of a deepening of the calcium compensation depth during the Campanian (Thierstein and Manivit, 1981). It is also possible that the occurrence of Braarudosphaera sp. and Nannoconus elongatus at a deep basinal setting such as Site 585 is evidence of the transport of pelagic material downslope.

Changes in the current regimes in the Pacific during the Maestrichtian, which actively eroded and transported underlying Campanian sediment, have been detected at other DSDP sites. This reworking, unlike that at Site 585, remained modest until the middle Eocene (Thiede et at., 1981). The presence of displaced and noncontemporaneous nannofossils in Upper Cretaceous and lower Tertiary sediment at Site 585 is evidence of their transport. The initiation of nannofossil deposition during the late Campanian (Ceratolithoides aculeus Zone) predates the proposed changes in the current regimes in the $\mathrm{Pa}$ cific; it is possible that these changes may have affected this site at an earlier time. It is also possible that the presence of upper Campanian calcareous sediment is related to late Campanian-Maestrichtian volcanic activity 
Table 4. Distribution and abundance of nannofossils in Cores 585-28 to 585-55.

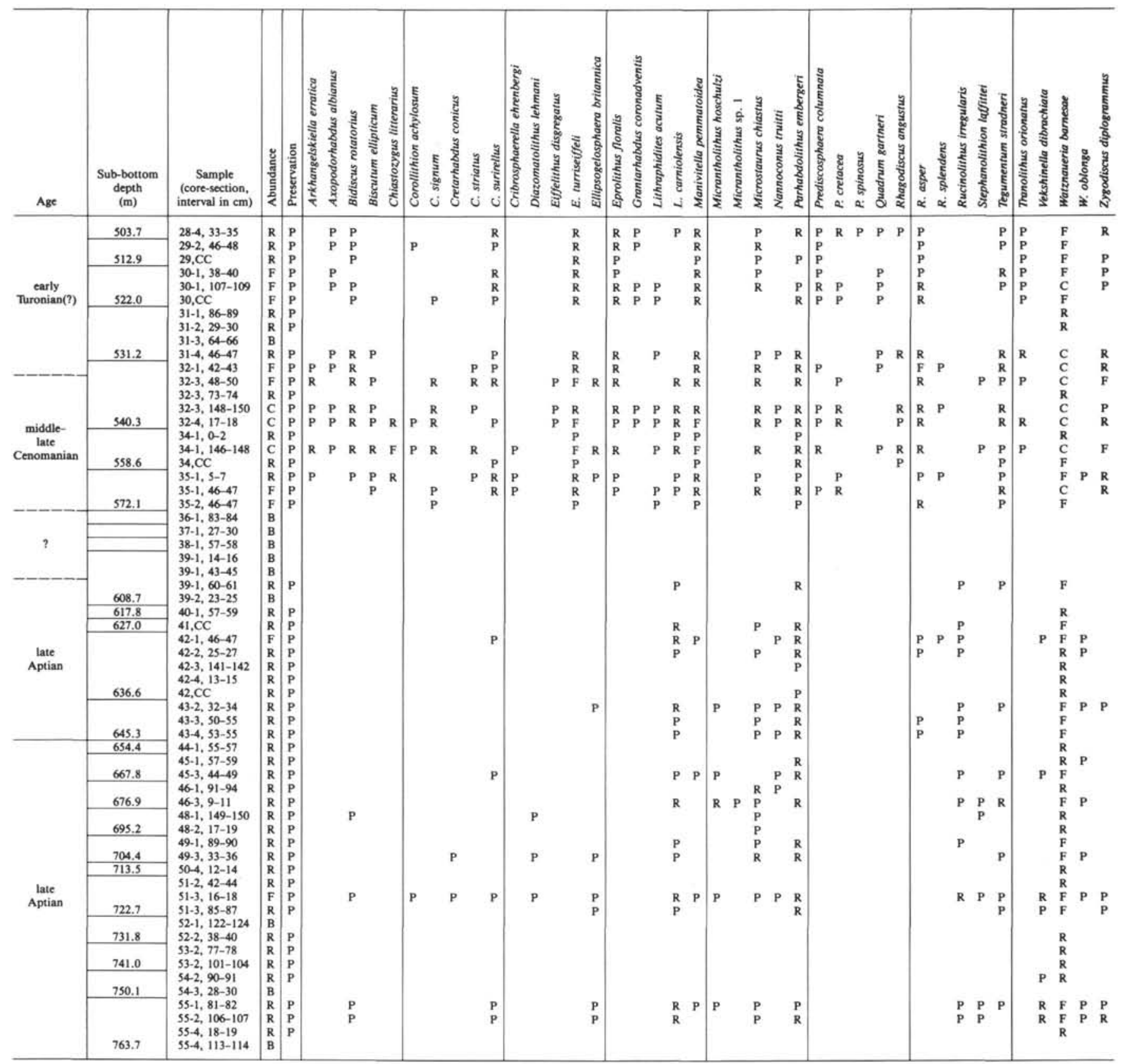

in the central western Pacific (Thiede et al., 1981), triggering turbidity currents on nearby seamounts such as Ita Maitai Guyot (located $70 \mathrm{~km}$ to the south).

Interpretations of late Aptian to Turonian assemblages are less concrete. The sparse, poorly preserved assemblages in $280 \mathrm{~m}$ of upper Aptian/lower Albian volcaniclastics show no apparent change in age, preservation, or abundance. This can be explained by their continual reworking, dilution by large volumes of rapidly deposited clastic sediment, or lack of biostratigraphic resolution. Assemblages in Cenomanian and Turonian sediments are more persistent and diverse, but are also poorly preserved. Microstaurus chiastus and Lithraphidites acutum in lower Turonian sediment have been reworked, and are the earliest definitive evidence of reworked nannofossil assemblages at this site.

\section{CONCLUSIONS}

Preliminary examination of material from these cores indicates that most, if not all, of the nannofossil assemblages are reworked. This contradicts evidence of an excursion of the calcium compensation depth below $5 \mathrm{~km}$ depth during Campanian-Maestrichtian time at two other deep-sea Pacific sites (Sites 199 and 462). More detailed sedimentological examination of sediment from these basinal sites in relation to reworked and displaced nannofossil assemblages (and other microfossils) is needed to determine the true depositional nature of this sediment. Drilling of reference sites on nearby volcanic edifices could provide valuable information on the source and stratigraphy of turbidites. The overwhelming dominance of the reworked portion of assemblages at certain 
Table 5. Distribution and abundance of nannofossils in Cores 585A-11 to 585A-21.

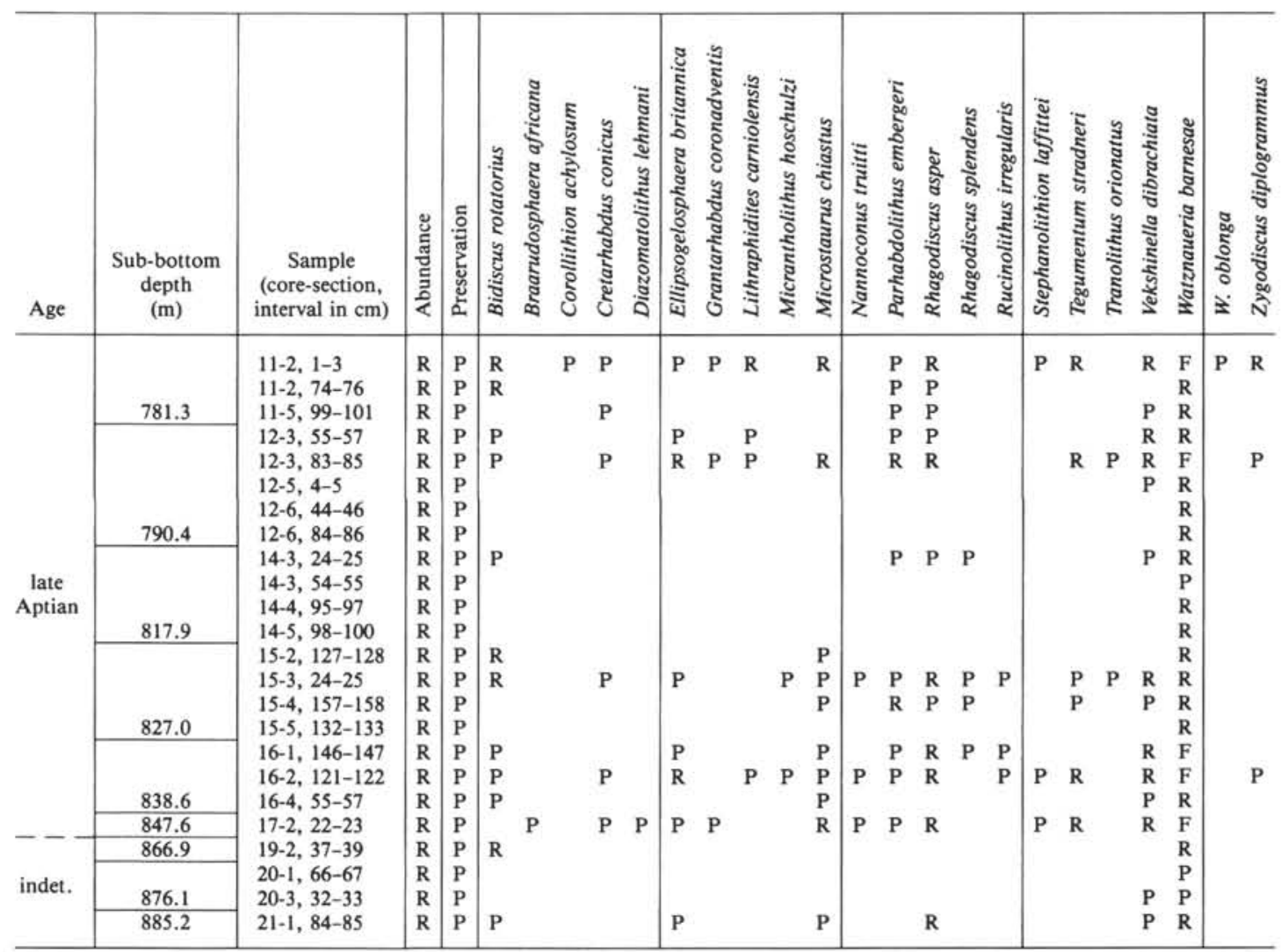

horizons demonstrates that caution must be exercised when examining and dating these assemblages.

\section{SYSTEMATIC PALEONTOLOGY}

\section{Genus QUADRUM Prins and Perch-Nielsen, 1977}

The genus Quadrum Prins and Perch-Nielsen, $1977,{ }^{3}$ for which the type species is Quadrum gartneri, includes several species previously assigned to the genus Tetralithus. The type species for the genus Tetralithus, Tetralithus pyramidus, is based on a nondescript form from the Miocene. Quadrum gartneri has since been considered a subjective junior synonym of Micula staurophora (Roth and Bowdler, 1979; Hattner and Wise, 1980). The genus Uniplanarius Hattner and Wise 1980 was erected to satisfy this taxonomic predicament.

In this paper, Quadrum gartneri is retained as a separate species for a small, obscure form similar to those illustrated by Manivit et al. (1977, plate 1, fig. 10) and Verbeek, (1977, plate 12, figs. 6-8). It is found only in Turonian sediment at Site 585. Typical Micula decussata (considered synonymous with Micula staurophora), which is larger and more cubic-shaped than $Q$. gartneri and possesses a distinct extinction pattern in cross-polarized light, does not occur in the Turonian samples examined; however, it is found as a common species in Campanian and Maestrichtian assemblages farther uphole. Also included within the genus Quadrum in this paper are: Quadrum trifidum, Quadrum gothicum, Quadrum quadratum, and Quadrum sp. 1.

\section{Quadrum sp. 1}

(Plate 1, Figs. 1-6)

Description. This form consists of two levels of four radial pieces of calcite and is assigned to the genus Quadrum. One layer possesses elements that are perpendicular to each other and taper to points at their tips. The second layer of elements are rotated $45^{\circ}$ to the first,

\footnotetext{
${ }^{3}$ See Manivit et al., 1977.
}

and have flattened tips. Individual elements in this second layer, although perpendicular to each other, are offset in a manner similar to that of Micula murus. The length and thickness of the elements in the second layer are variable.

Remarks. Quadrum sp. most closely resembles Quadrum nitidum (Martini, 1961) Prins and Perch-Nielsen, 1977, from which it differs by possessing a layer of radial elements that are offset and have flattened tips.

Occurrence. This form is rare in samples from upper Campanian through middle Eocene sediments in Hole 585 and Sample 585A-3-1, 64-65 $\mathrm{cm}$. The Tertiary occurrences are probably reworked specimens, because this form has taxonomic affinities with Cretaceous species.

\section{Braarudosphaera sp. 1}

(Plate 1, Figs. 7-8)

Braarudosphaera sp. indet. Thierstein and Manivit, 1981 (plate 7, figs. 1-4).

Braarudosphaera sp. 1 Monechi (in press), (plate 1, figs. 1-10, 12).

Remarks. The comments in Monechi (in press) apply to specimens seen in the Site 585 material. Variation in the length of the rays due to overgrowth is observed.

Occurrence. This form has been reported in Campanian sediment at two other DSDP Pacific sites, Sites 576 and $\mathbf{4 6 2}$. It is likely that specimens observed in Maestrichtian and Paleogene sediment at this site are reworked.

\section{ACKNOWLEDGMENTS}

I am grateful to Dr. S. W. Wise and the Deep Sea Drilling Project for giving me the opportunity to participate on Leg 89 . I would like to thank Dr. H. R. Thierstein and Dr. M. Filewicz for their helpful suggestions in reviewing this manuscript.

\section{REFERENCES}

Hattner, J., and Wise, S. W., 1980. Upper Cretaceous calcareous nannofossil biostratigraphy of South Carolina. South Carolina Geol., 24,(2):41-117. 
Krasheninnikov, V. A., 1981. Paleogene planktonic foraminifers from Deep Sea Drilling Project Leg 62 sites and adjacent areas of the northwest Pacific. In Thiede, J., Vallier, T. L., et al., Init. Repts. DSDP, 62: Washington (U.S. Govt. Printing Office), 365-376.

Manivit, H., Perch-Nielsen, K., Prins, B., and Verbeek, J. W., 1977. Mid-Cretaceous calcareous nannofossil biostratigraphy, $K$. Acad. Nederlandse Wet., Ser. B, 80(3):169-181.

Martini, E., 1961. Nannoplankton aus dem Tertiar und der obersten Kriede von SW-Frankreich, Senckenbergiana Lethaea, 42(1/2):141.

Monechi, S., (in press). Calcareous nannofossil stratigraphy from the northwest Pacific Ocean. In Heath, G. R., Burkle, L. H., et al., Init. Repts. DSDP, 86: Washington (U.S. Govt. Printing Office).

Okada, H., and Bukry, D., 1980. Supplementary modification and introduction of code numbers to the low-latitude coccolith biostratigraphic zonation (Bukry, 1973; 1975). Mar. Micropaleontol., 5: 321-325.

Okada, H., and Thierstein, H. R., 1979. Calcareous nannoplanktonLeg 43, Deep Sea Drilling Project. In Tucholke, B. E., Vogt, P. R., et al., Init. Repts. DSDP, 43: Washington (U.S. Govt. Printing Office), 507-573.

Perch-Nielsen, K., 1979. Calcareous nannofossils from the Cretaceous between the North Sea and the Mediterranean. Aspekte Kriede Europas IUGS Ser. $A, 6: 223-272$.

Roth, P. H., and Bowdler, J. L., 1979. Evolution of the calcareous nannofossil genus Micula in the Late Cretaceous Micropaleontol., 25(3):272-280.

Thiede, J., Boersma, A., Schmidt, R. R., and Vincent, E., 1981. Reworked fossils in Mesozoic and Cenozoic pelagic central Pacific Ocean sediments, Deep Sea Drilling Project Sites 463, 464, 465, and 466, Leg 62. In Thiede, J., Vallier, T. L., et al., Init. Repts. DSDP, 62: Washington (U.S. Govt. Printing Office), 495-512.

Thierstein, H. R., 1976. Mesozoic calcareous nannoplankton biostratigraphy of marine sediments, Mar. Micropaleontol., 1:325-362.

1979. Paleoceanographic implications of organic carbon and carbonate distribution in Mesozoic deep-sea sediments. In Talwani, M., Hay, W., and Ryan, W. B. F. (Eds.), Deep Drilling Results in the Atlantic Ocean: Continental Margins and Paleoenvironment. Maurice Ewing Ser. 3, Am. Geophys. Union (Washington, D. C.), 249-274.

1980. Selective dissolution of Late Cretaceous and earliest Tertiary calcareous nannofossils: experimental evidence. Cretaceous Res., 2:165-176.

Thierstein, H. R., and Manivit, H., 1981. Calcareous-nannofossil biostratigraphy, Nauru Basin, Deep Sea Drilling Project Site 462, and Upper Cretaceous nannofacies. In Larson, R. L., Schlanger, S. O., et al., Init. Repts. DSDP, 61: Washington (U.S. Govt. Printing Office), 475-494.

Verbeek, J. W., 1977. Calcareous Nannoplanktonic Biostratigraphy of Middle and Upper Cretaceous Deposits in Tunesia, Southern Spain, and France. Utrecht Micropaleontol. Bull., 16.

Date of Initial Receipt: 14 May 1984

Date of Acceptance: 13 July 1984

\section{APPENDIX}

Nannofossil Taxa Used in This Chapter

\section{Cretaceous species}

Actinozygus regularis (Gorka, 1957) Gartner, 1968

Arkhangelskiella cymbiformis Vekshina, 1959

Arkhangelskiella erratica Stover, 1966

Axopodorahabdus albianus (Black. 1967) Wind and Wise, 1976

Bidiscus rotatorius Bukry, 1969

Biscutum ellipticum (Gorka, 1957) Grün and Zweili, 1980

Braarudosphaera africana Stradner, 1961

Braarudosphaera sp.

Broinsonia parca (Stradner, 1963) Bukry, 1969

Ceratolithoides aculeus (Stradner, 1961) Prins and Sissingh, 1977

Chiastozygus litterarius (Gorka, 1957) Manivit, 1971

Corollithion achylosum (Stradner, 1966) Thierstein, 1971

Corollithion signum Stradner, 1963

Cretarhabdus conicus Brammlette and Martini, 1964

Cretarhabdus schizobrachiatus (Gartner, 1968) Bukry, 1969
Cretarhabdus striatus (Stradner, 1963) Black, 1973

Cretarhabdus surirellus (Deflandre and Fert, 1954) Reinhardt, 1970 Cribrosphaerella ehrenbergi (Arkhangelsky, 1912) Deflandre, 1952 Cylindralithus sp.

Diazomatolithus lehmanii Noel, 1965

Eiffellithus disgregatus (Stover, 1966) Hoffmann, 1970

Eiffellithus eximius (Stover, 1966) Perch-Nielsen, 1968

Eiffellithus trabeculatus (Gorka, 1957) Reinhardt and Gorka, 1967

Eiffellithus turriseiffeli (Deflandre, 1954) Reinhardt, 1965

Ellipsagelosphaera britannica (Stradner, 1963) Perch-Nielsen, 1968

Eprolithus floralis (Stradner, 1962) Stover, 1966

Gartnerago obliquum (Stradner, 1963) Reinhardt, 1970

Grantarhabdus coronadventis (Reinhardt, 1966) Grün, 1975

Kamptnerius magnificus Deflandre, 1959

Lithraphidites acutum Verbeek and Manivit, 1977

Lithraphidites carniolensis Deflandre, 1963

Lithraphidites quadratus Bramlette and Martini, 1964

Manivitella pemmatoidea (Deflandre and Manivit, 1965) Thierstein, 1971

Marthasterites furcatus (Deflandre, 1954) Deflandre, 1959

Micrantholithus hoschulzi (Reinhardt, 1966) Thierstein, 1971

Micrantholithus sp. 1 Perch-Nielsen, 1979

Microrhabdulinus ambiguus Deflandre, 1963

Microrhabdulus decoratus Deflandre, 1959

Microstaurus chiastus (Worsley, 1971) Grün, 1975

Micula concava (Stradner, 1960) Bukry, 1969

Micula decussata Vekshina, 1959

Micula murus (Martini, 1961) Bukry, 1973

Nannoconus elongatus subsp. cylindrus Deflandre and Deflandre, 1960

Nannoconus truitti Bronnimann, 1955

Parhabdolithus embergeri (Noel, 1958) Stradner, 1963

Prediscosphaera columnata (Stover, 1966) Manivit, 1971

Prediscosphaera cretacea (Arkhangelsky, 1912) Gartner, 1968

Prediscosphaera grandis Perch-Nielsen, 1979

Prediscosphaera spinosa (Bramlette and Martini, 1964) Gartner, 1968

Quadrum gartneri Prins and Perch-Nielsen, 1977

Quadrum gothicum (Deflandre, 1959) Prins and Perch-Nielsen, 1977

Quadrum quadratum (Stradner, 1961) Verbeek, 1977

Quadrum trifidum (Stradner, 1961) Prins and Perch-Nielsen, 1977 Quadrum sp.

Reinhardtites anthophorus (Deflandre, 1959) Perch-Nielsen, 1968 Rhagodiscus angustus (Stradner, 1963) Reinhardt, 1971

Rhagodiscus asper (Stradner, 1963) Reinhardt, 1967

Rhagodiscus splendens (Deflandre, 1953) Verbeek, 1977

Rucinolithus irregularis Thierstein, 1972

Rucinolithus magnus Bukry, 1975

Stephanolithion laffittei Noel, 1957

Tegumentum stradneri Thierstein, 1972

Tetrapodorhabdus decorus (Deflandre, 1954) Wind and Wise, 1976

Thoracosphaera operculata Bramlette and Martini, 1964

Thoracosphaera saxea Stradner, 1961

Tranolithus orionatus (Reinhardt, 1966) Reinhardt, 1966

Vekshinella dibrachiata Gartner, 1968

Watznaueria barnesae (Black, 1959) Perch-Nielsen, 1968

Watznaueria oblonga Bukry, 1969

Zygodiscus diplogrammus (Deflandre, 1954) Gartner, 1968

Zygodiscus spiralis Bramlette and Martini, 1964

\section{Cenozoic species}

Biantholithus sparsus Bramlette and Martini, 1964

Calcidiscus macintyrei (Bukry and Bramlette, 1969) Loeblich and Tappan, 1978

Campylosphaera eodela Bukry and Percival, 1971

Ceratolithus rugosus Bukry and Bramlette, 1968

Chiasmolithus californicus (Sullivan, 1964) Hay and Mohler, 1967

Chiasmolithus consuetus (Bramlette and Sullivan, 1961 Hay and Mohler, 1967

Chiasmolithus danicus (Brotzen, 1959) Bramlette and Martini, 1964

Chiasmolithus expansus (Bramlette and Sullivan, 1961) Gartner, 1970 


\section{J. A. BERGEN}

Coccolithus cavus Hay and Mohler, 1967

Coccolithus crassus Bramlette and Sullivan, 1961

Coccolithus formosus (Kamptner, 1963) Wise, 1973

Coccolithus pelagicus (Wallich, 1877) Schiller, 1930

Crenalithus doronicoides (Black and Barnes, 1961) Roth, 1973

Cruciplacolithus primus Perch-Nielsen, 1977

Cruciplacolithus tenuis (Stradner, 1961) Hay and Mohler, 1967

Cyclagelosphaera reinhardtii (Perch-Nielsen, 1968) Romein, 1977

Cycloccolithus gammation (Bramlette and Sullivan, 1961) Sullivan, 1964

Discoaster barbadiensis Tan Sin Hok, 1927

Discoaster brouweri Tan Sin Hok, 1927

Discoaster lenticularis Bramlette and Sullivan, 1961

Discoaster lodensis Bramlette and Riedel, 1954

Discoaster mediosus Bramlette and Sullivan, 1961

Discoaster mohleri Bukry and Percival, 1971

Discoaster multiradiatus Bramlette and Riedel, 1954

Discoaster nobilis Martini, 1961

Discoaster pentaradiatus Tan Sin Hok, 1927

Discoaster quinqueramus Gartner, 1969

Discoaster sublodoensis Bramlette and Sullivan, 1961

Discoaster surculus Martini and Bramlette, 1963

Discoaster variabilis Martini and Bramlette, 1963

Ellipsolithus mecellus (Bramlette and Sullivan, 1961) Sullivan, 1964

Ericsonia supertusa Hay and Mohler, 1967

Ericsonia universa (Wise and Wind, 1976) Romein, 1977

Fasciculithus tympaniformis Hay and Mohler, 1967

Gephyrocapsa caribbeanica Boudreaux and Hay, 1967

Heliolithus kleinpellii Sullivan, 1964

Heliolithus riedelii Bramlette and Sullivan, 1961

Markalius inversus (Deflandre, 1954) Bramlette and Martini, 1964

Neochiastozygus concinnus (Martini, 1961) Perch-Nielsen. 1971

Neochiastozygus distentus (Bramlette and Sullivan, 1961) PerchNielsen, 1971
Neocrepidolithus neocrassus (Perch-Nielsen, 1968) Romein, 1977 Prinsius bisulcus (Stradner, 1963) Hay and Mohler, 1967 Pseudoemiliania lacunosa (Kamptner, 1963) Gartner, 1969 Reticulofenestra pseudoumbilica (Gartner, 1967) Gartner, 1969 Sphenolithus abies Deflandre, 1954

Sphenolithus sp. cf. S. conspicuus Martini, 1976

Sphenolithus neoabies Bukry and Bramlette, 1969 Sphenolithus primus Perch-Nielsen, 1971

Toweius eminens (Bramlette and Sullivan, 1961) Gartner, 1971 Tribrachiatus contortus (Stradner, 1958) Bukry, 1972

Tribrachiatus nunnii (Bronnimann and Stradner, 1960) Gartner, 1971

Zygodiscus plectopons Bramlette and Sullivan, 1961

Zygodiscus sigmoides Bramlette and Sullivan, 1961

\section{REFERENCES}

Loeblich, A. R., Jr., and Tappan, H., 1966. Annotated index and bibliography of the calcareous nannoplankton. Phycologica, 5(2 and 3):81-216.

, 1968. Annotated index and bibliography of the calcareous nannoplankton. II. J. Paleontol., 42(2):584-598.

, 1969. Annotated index and bibliography of the calcareous nannoplankton. III. J. Paleontol., 43:568-588.

, 1970. Annotated index and bibliography of the calcareous nannoplankton. IV. J. Paleontol., 44(3):558-574.

,1970. Annotated index and bibliography of the calcareous nannoplankton. V. Phycologica, 9(2):157-174.

, 1971. Annotated index and bibliography of the calcareous nannoplankton. VI. Phycologica, 10(4):315-339.

1973. Annotated index and bibliography of the calcareous nannoplankton. VII. J. Paleontol., 47(4):715-759. 

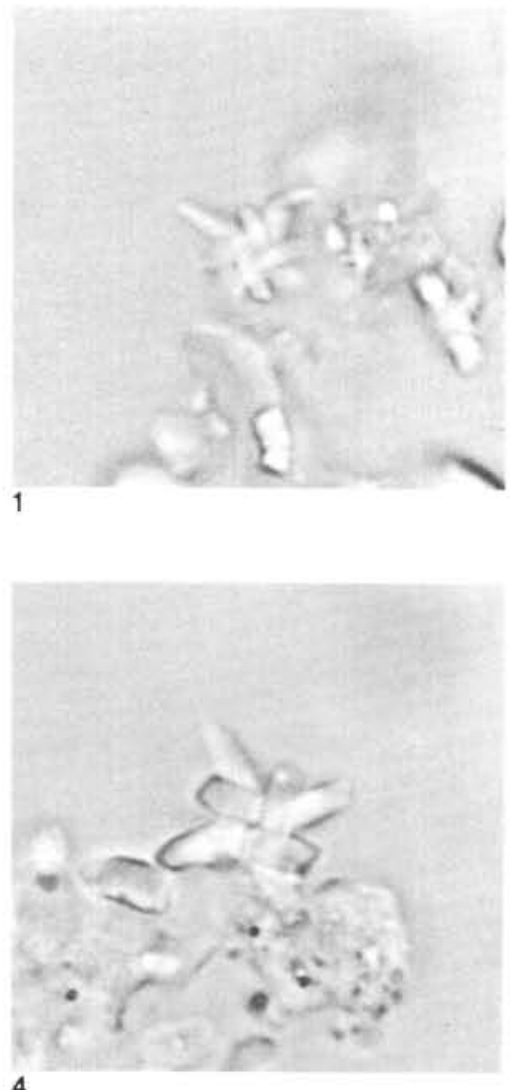

4

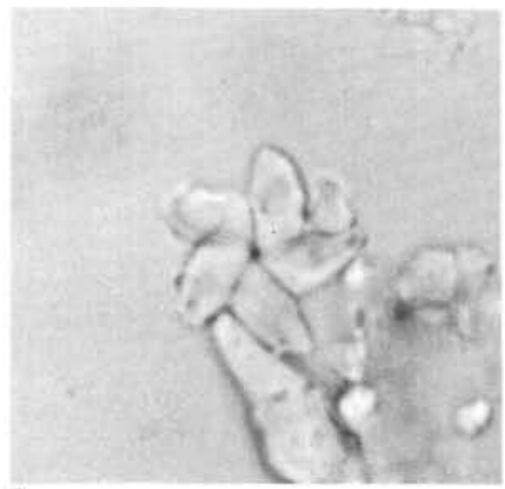

7
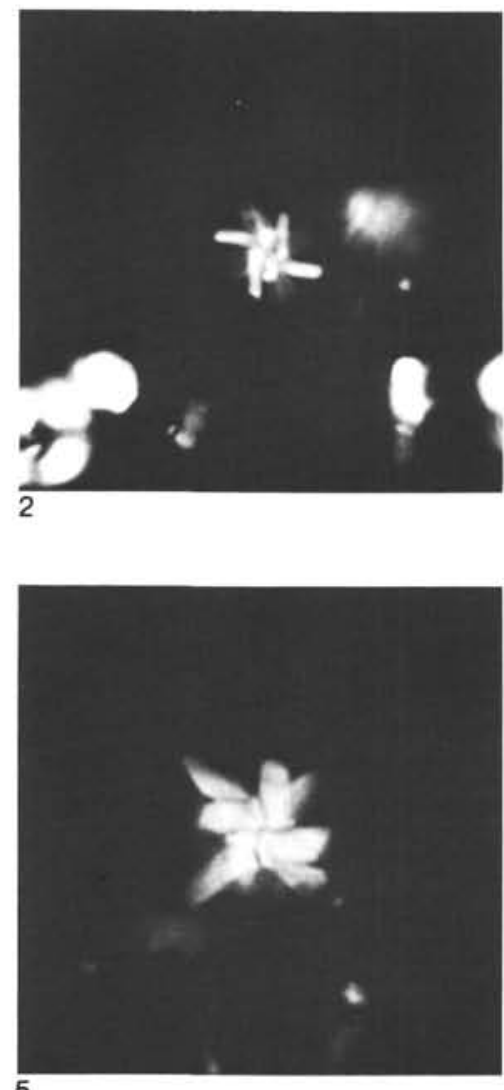

5

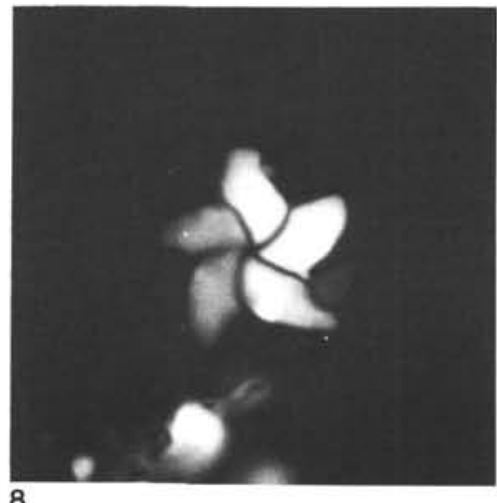

8

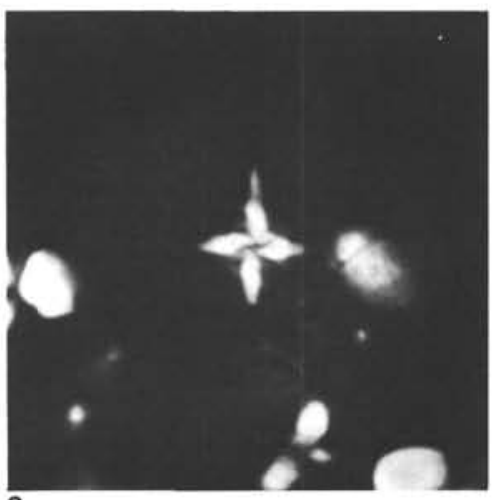

3

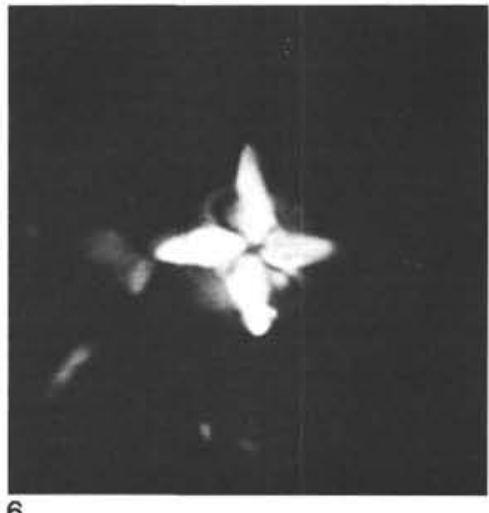

6

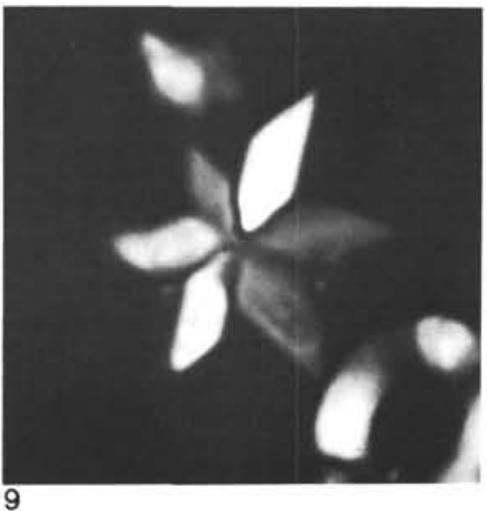

Plate 1. All photographs $\times 2670 ; \mathrm{XP}=$ cross-polarized light; $\mathrm{TL}=$ transmitted light. 1-3. Quadrum sp. 1, Sample 585-20-3, 52-53 cm. (1) TL; $(2,3)$ XP. 4-6. Quadrum sp. 1, Sample 585-20-3, 52-53 cm. (4) TL; $(5,6)$ XP. 7-8. Braarudosphaera sp. 1, Sample 585-20-3, 52-53 cm. (7)

TL; (8) XP. 9. Rucinolithus magnus Bukry, Sample 585-20-3, 108-109 cm. XP. 

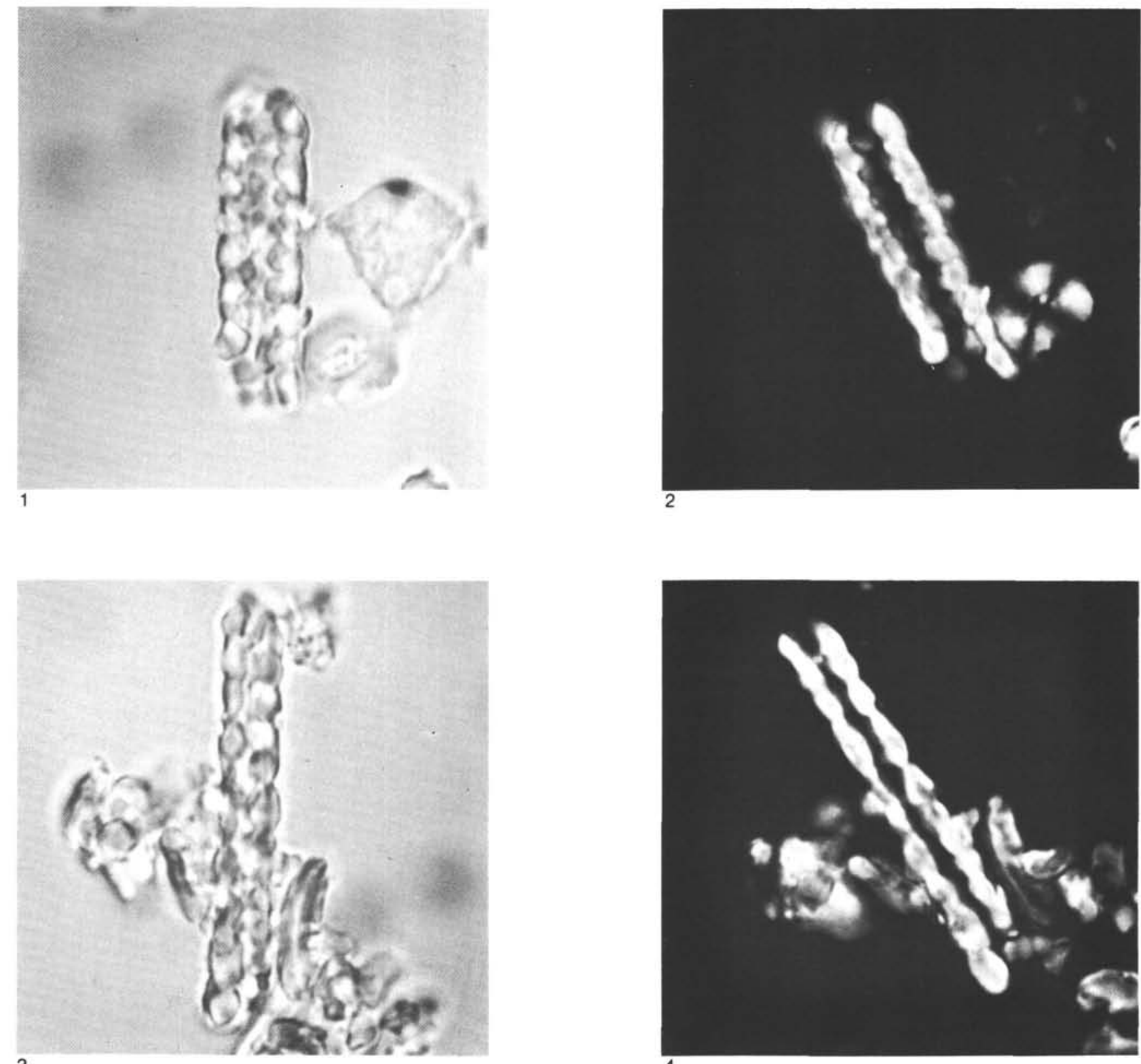

3

Plate 2. All photographs $\times 2670 ; \mathrm{XP}=$ cross-polarized light; $\mathrm{TL}=$ transmitted light. $1-2$. Nannoconus elongatus subsp. cylindrus Deflandre and Deflandre, Sample 585-20-3, 52-53 cm. (1) TL; (2) XP. 3-4. Nannoconus elongatus subsp. cylindrus Deflandre and Deflandre, Sample 585A-3-1, 64-65 cm. (3) TL; (4) XP. 